\title{
Complex exploitation of the Far East mineral resources: effects "new model" of the macroregional development
}

\author{
Natalia Lomakina ${ }^{1 *}$ \\ ${ }^{1}$ Economic Research Institute of Far Eastern Branch of the Russian Academy of Sciences \\ 680042, Khabarovsk, 153 Tikhookeanskaya St.
}

\begin{abstract}
The responses of economic agents in the mineral resources sector to the implantation of instruments of the "new model" of development of the Far Eastern Federal District in 2014-2020 is investigated. At the same time, the emphasis is put on assessing the capabilities of these instruments to stimulate the integrated development of the region's strategic mineral resources. It was reveal is that within the framework of the "new model" there are no targets and measures aimed at technological modernization and development of processing industries in the mineral resources sector of the region. At the same time, the implemented measures of state support are actually aim at hypertrophied development of the raw stock component of the mineral resources sector. The potential and key directions in connection with the formation of new sub-sectors for the final processing of mineral resources of the Far Eastern Federal District have been shown. Changes to the model of state incentives for the development of the mineral resources sector in the Far East are proposed.
\end{abstract}

\section{Introduction}

The issues of integrated development of natural resources are relevant for territories with rich mineral wealth potential. These territories include the Far Eastern Federal District (FEFD), namely, 11 constituent entities of the Russian Federation. For most of them, the extraction of mineral resources (EMR) is part of the economic industry, covering from 4550\% (Amur Region and Jewish Autonomous Region) to 85-90\% (Yakutia Republic and Chukotka Autonomous District, Magadan and Sakhalin Regions) in the industrial structure. Therefore, the comprehensive used of mineral resources (MR), growth chain processes and increase the added value mineral resources complex (MRC) determines the success of development of the entire regional economy

For the MRC of the FEFD, the conditions of long-term competitiveness shown in the framework of the foresight forecast of its development until 2050 [1]. At the same time, the institutional conditions are also important for the formation of its "new look", both reproductive and technological.

\footnotetext{
${ }^{*}$ Corresponding autor: lomakina@ecrin.ru
} 
Special institutional conditions for state incentives are implementing in the Far East since 2014, established within the framework of the region's "new development model". This new situation makes a number of research questions relevant. Are there any opportunities for diversification and weakening of the predominantly raw stock nature of the development of the FEFD in the near future? Do preferential regimes work to stimulate the creation in the region of industries for the final processing of mined mineral resources? Finding answers to these questions is the purpose of this paper.

\section{Theoretical and methodological aspects of study}

A lot of works are devoted to the study of the problems of territorial systems development with a predominantly raw stock specialization of the economy and assessment of the mechanisms and consequences of state regulation [2-6]. Within the framework of this problematic, the issues of not only resource availability (as determined by natural-sectoral characteristics), but also resource dependence, formed under the influence of the institutional environment and economic policy [7], are investigated.

For the Far East, the forms and individual results of state participation in its development are analyzing at various historical stages [8] and within the framework of the modern "new management model" [9, 10]. The object of consideration in this paper is the MRC of the FEFD, which is one of the most stable in times of crisis and leading in periods of economic recovery. An assessment of the first results of the individual instruments implementation of the "new model" of regional development in the MRC and monitoring of investment activity in this sector $[9,11]$ revealed its increasing importance.

The author has examined the responses of economic agents in the MRC to the implantation of instruments of the "new model" of development of the FEFD. At the same time, the emphasis is put on assessing capabilities of these instruments to stimulate the integrated development of the region's strategic mineral resources. The period of 20142020, reflecting the first results of the implementation of the "new model" for the development of the FEFD, are studied. Official statistical data, regulatory documents, analytical and expert assessments were used as the information sources.

\section{Results and discussion}

\subsection{Mechanisms of the "new model" of development and resource dependence of the economy of the Far East}

The modernization of the resource sector has traditionally been identified as one of targets for the development of the Far East. In particular, those tasks were set in the latest version of the state program for the development of the Far East until 2025, adopted on the eve of the formation of the "new model" for the region's development. The mineral sector was identified as one of the key priorities and drivers for the development of the region's economy. The directions of its long-term development and expected performance were formulated in a special subprogram. However, the analysis of the forecasted indicators of the program showed no growth in the share of the manufacturing industry in the structure of the regional economy in the long term. Moreover, in those constituent entities of the Russian Federation, where it was planned to implement large mineral and raw projects, the share of the manufacturing industry decreased. With the declared modernization tasks, one would expect an increase in the raw component in the development of the region in real practice [12]. 
Within the framework of the "new model" announced in 2014, one of the first tasks was to update the State Program for the Development of the Far East. To date, many versions of the new state program have already been adopted (including the latest version dated March 25, 2020). Meantime, there are no special sections and target tasks related to the technological modernization of the MRC in the new program.

The most significant measures within the framework of the "new model" of development of the FEFD, capable of affecting structural changes in the economy, were as follows:

- direct subsidies from the federal budget for infrastructure costs of key investment projects;

- a set of preferential regimes within localized territories;

- extraterritorial preferential regimes.

As an analysis has shown, in practice these general-purpose preferential measures turned out to be actively stimulating precisely the resource industries, primarily mining (MI).

As for the mechanism of direct state support for investment projects to solve infrastructure problems, it could work towards the formation of a diversified sectoral structure in the Far Eastern region. Subsidies from the federal budget for the implementation of this mechanism in 2015-2020 were planned 32.5 billion rubles worth, with more than $90 \%$ of these funds allocated to support mineral projects. In fact, it is the mineral resource projects that are recognized as the most competitive not only for private investors, but also for the state. A positive significance of the impact of this instrument of state support for expanding the mineral base should be noted: 1) new deposits that did not have such prospects before may be involved in the development, and 2) the opportunities for activities by "junior" companies in the Far East are expanding. But as a result, this mechanism stimulates a further growth of mineral wealth sectors in the structure of the economy of the Far Eastern macroregion.

The response of economic agents in the mineral sector to preferential regimes within localized territories (for example, advanced development territories, or ADT) turned out to be active. At the beginning of 2020, 20 ADTs were creating in ten Russian regions in the FEFD. When companies were included in the ADT residents, priority was supposed to be given to full-cycle industries, and above all to projects in the manufacturing sector based on the primary resources of the Far East. The analysis showed that out of almost 500 projects included in the Register of ADTs residents, about a hundred are in varying degrees related to mining. Preferences are most in demand in the main resource regions (Yakutia, Kolyma, Chukotka), where the MRC forms a significant part of regional budgets. Characterizing the development of this preferential regime from the standpoint of the actual implementation of projects, it is resource projects (and above all in MI) that prevail - from 67 to $100 \%$ of implemented projects in various territories of the FEFD. The structure of investments in projects, showing the investment activity of ADT residents, reflects the situation more adequately. Here the estimates are even clearer: the share of investments in resource projects is dominant in most regions of the FEFD. At the same time, in four regions - in Yakutia and Chukotka, in Amur and Jewish Autonomous Regions - resource projects account for almost the entire volume of investments in ADTs [13]. The above analysis demonstrates the preservation and consolidation of a tendency for the predominance of investments in mineral projects among the total volume of investments in fixed assets in the FEFD [11].

Such an instrument as obtaining the status of a "regional investment project" (RIP) was also in demand in the mineral sector of the Far East. The key preferences within the framework of this instrument are income tax and mineral wealth tax incentives, therefore, mineral companies were active. The RIP regime went through several stages in its 
development: 1) 2014-2016, strict requirements for applicants for preferences, the formation of a special Register of RIP and the inclusion of projects in it by the decision of regional authorities; 2) after 2016, under pressure from mineral companies at the federal level, significant amendments were made - liberalization of the financial threshold (in terms of investment), a change in the period of validity of preferences (for investments made from January 1, 2013), the introduction of a notification procedure for obtaining preferences (without coordination with regional authorities and inclusion in the register). An unexpected loss of control over these processes at the regional level, a threat of growth of uncontrolled shortfalls in income in regional budgets led to active actions by the governing bodies of particular Russian regions (Chukotka Autonomous District, Khabarovsk Territory, etc.) to abandon these preferences.

If we return to the initial tasks of special incentive measures implemented by the state in the Far East, then one of the most important is the growth of investment activity in the region. The mineral sector has been one of the drivers of investment activity in the region for many years; the preferences of the "new model" of the region's development contribute to its further growth. As a result, the tendencies of strengthening the mineral nature of the economy of the FEFD were established: by 2020, relative to 2013, the share of foreign economic activity of mining grew in the structure of industrial production both in the macroregion as a whole and in key mineral wealth territories (Yakutia, Magadan, Chukotka) [13].

\subsection{Potential for technological modernization and development of processing industries in the MRC FEFD}

The absence of measures "sharpened” for the technological modernization of the region's mineral sector within the framework of the "new model” being implemented in the FEFD does not mean the absence of such potential. To date, there are at least three key areas for the formation of new sub-sectors based not only on mining and concentration, but also on final processing of mineral resources, particularly in the fields of rare earth metals, copper industry and ferrous metallurgy.

The presence of the of mineral resource potential in the Far East for the formation of the rare earth metals industry (REM) has long been well known [1]. However, a unique situation is now emerging: one of the largest rare earth deposits in the world, Tomtor in Yakutia, is actually being prepared for development. The total investment in its development will be over 55 billion rubles worth. The development of the deposit involves ore extraction at Buranny site and construction of a hydrometallurgical plant (HMP) for its processing in Krasnokamensk (Trans-Baikal Territory). Production at Tomtor is planned to begin in 2022, the launch of Krasnokamensk HMP - in 2025. Technological research and optimization of the processing flow chart are ongoing. The manufacturer plans to occupy a dominant position in the European market and provide up to $10 \%$ of the world supply of rare earth metals [14]. A necessary condition for the implementation of such approach is the development of government support measures at all stages of the technological chain.

Taking into account the resource potential of the Far East and its competitive position practically in the center of the North-East Asia with intensively developing high-tech industries and transport, as well as the task set within the framework of the "new model" to form international cooperation centers, it may be quite appropriate to search for opportunities to form such international centers for processing REM [15] in the macroregion.

Another possible direction for the formation of an integrated complex - from the extraction of resources to the consumption of final products - can be ferrous metallurgy. The history of research of ferrous metallurgy's opportunities in the Far East dates back to 
the 1960s. One of the key tasks under centralized planning was the selection of the site and technologies for metallurgical plant. The possibilities of locating a plant in Yakutia, Amur Region, or Khabarovsk Territory with Jewish Autonomous Region, which was then a part of it, were considered and evaluated. Currently, the construction of the Kimkano-Sutarsky mining and processing plant (KSGOK) for the extraction and processing of iron ores has been completed in Jewish Autonomous Region. The production capacity of the first line is 10 million tons per year of run-of-mine ore and 3.15 million tons of iron ore concentrate with $65 \%$ iron content. In the future, it is planned to concentrate 7.25 million tons of ore from the Garinskoye deposit (Amur Region) at KSGOK.

One of the projects that can create incentives for the formation of the final processing of ferrous metals in the Far Eastern Federal District may be an active revival of shipbuilding in the region. One of major national projects was the launch of Zvezda shipyard (Primorsk Territory) and the construction of modern Russian gas carriers, which has already begun. An agreement was signed with South Korean Samsung Heavy Industries to supply the components for NOVATEK's Arctic LNG-2 project for the first five vessels under construction. The transaction amount is about USD 1.5 billion, while the volume of work of the Korean shipyard may amount to about $75 \%$ of the final cost of the vessel [16]. Given the lack of experience in building gas carriers in Russia, a scheme of close cooperation with Samsung is necessary. But in the long term, this can be considered the volume of demand, which includes the demand for metal. An important element in the construction of new Russian gas carriers is the fulfillment of the requirements of the Government of the Russian Federation for the localization of ships. Small fishing vessels and vessels that are being built in the Far East as a prerequisite for admission to crab auctions must also meet these requirements. Elements that increase the degree of localization include, inter alia, metal cutting, as well as using Russian raw stock.

In the author's opinion, this creates a hypothetical possibility to develop the missing stages of the full metallurgical cycle in the Far Eastern Federal District, and this can be done on the most modern technological basis, taking into account economic opportunities and environmental restrictions.

An equally interesting situation is developing in the macroregion with regard to the opportunities of developing copper resources and forming on this basis a new industry in the mineral sector of the FEFD. Today, a “copper triangle” is clearly emerging, based on large projects in Trans-Baikal and Khabarovsk Territories and Chukotka Autonomous District.

In Khabarovsk Territory, the Malmyzhsk deposit (with reserves of more than 5 million tons of copper and 270 tons of gold) is getting prepared for development with the launch of a mining and processing plant in 2023-2024. The projected capacity is 35-56 million tons of ore with a predominantly export orientation, the project cost being 115 billion rubles [17]. The Baimsk porphyry and copper deposit is being developed in Chukotka (current resources according to the JORC code are 9.5 million tons of copper and more than 500 tons of gold). Investments in the project are estimated at USD 5.5 billion; the launch is scheduled for 2024. To support the project in 2019, the boundaries of the Beringovsky ADT, created in 2015, were significantly expanded and it was renamed into the Chukotka ADT (with a total area of more than 26 million hectares) [18].

Of course, all these projects are very challenging. Only look at the many years of attempts, including those with the governmental participation, to develop a unique copper deposit Udokan in Transbaikalia (still not developed), is enough to assess these difficulties.

One cannot but positively assess the social and budgetary significance of these projects, but their impact on the change in the structure of the economy of the Far Eastern Federal District and the formation of high-tech processing in the region's mineral sector is not even discussed. As before, the point is the raw model of using quite unique resources. 
Apparently, it is necessary to work with the "copper triangle" as a whole, not in the form of target preferences for individual projects. In addition, all three territories with the largest copper projects are in a new management situation - in a single preferential macroregion, for which a special federal governing body with significant powers has been created (the Ministry for the Development of the Russian Far East).

\section{Conclusions}

The study showed that within the framework of the "new model" for the development of the Far East, there are no targets and measures aimed at technological modernization and the development of processing within the industries of the region's mineral sector. At the same time, a significant number of general (not related to mining) governmental support measures actually turned out to be aimed at hypertrophied development of the raw component of the mineral resources.

In the author's opinion, the model of state stimulation of the mineral sector development in the Far East requires somewhat fundamental changes - the focus should be shifted to stimulating the final consumption of mineral resources in the region. A more accentuated formulation of the target task is needed for the long-term development of the regional economy -the creation of a sector of high-tech industries based on the use of mineral resources of the Far East. Therefore, the question is to change the "point of application" of known measures and instruments of state industrial policy (loans, rates, etc.).

At the same time, in addition to resources, the Far Eastern macroregion also has a number of institutional competitive advantages - a whole set of preferential regimes and measures already effective within the framework of the implementation of the "new model" of regional development. Competent consolidation of standard industrial policy measures with the implemented special preferential regimes has a chance to change the economic view for the time being of the still resource-based region.

\section{References}

1. Synthesis of scientifically technical and economic forecasts: Pacific Russia - 2050 edited by P.A. Minakir, V.I. Sergienko, Vladivostok: Dalnauka (2011)

2. V.A Kryukov. Spatial Econ., 4, 26-60 (2014)

3. M. Alexeev, A. Chernyavskiy, Natural Resources and Economic Growth in Russia's Regions. Working papers. Series: Economics. WP BRP 55/ec/2014 (2014)

4. J. Cust, S. Poelhekke. The Local Economic Impacts of Natural Resource Extraction. The OxCarre Working Paper №156. Oxford Centre for the Analysis of Resource Rich Economies. (2015)

5. Pyzhev, A.I, Syrtsova, E.A., Pyzheva, Yu. I., Zander, E.V. J. Sib. Fed. Univ. Humanit. Soc. Sci., 8 (11), 2590-2595 (2015)

6. G.I.Popodko, O.S. Nagaeva.J. Sib. Fed. Univ. Humanit. Soc. Sci., 12(12), 2309-2325 (2019)

7. M.V. Kurbatova, S.N. Levin, E.S., Kagan, D.V. Kislitsyn. Journ. Terra Econom. 17(3), 89-106 (2019)

8. P.A. Minakir, O.M. Prokapalo.Journ.ECO, 4, 5-26 (2017)

9. N.E. Antonova, N.V. Lomakina.Econ. \& Soc. Changes: Facts, Trends, Forecast, 11(1), 43-56. (2018)

10. D.A. Izotov, Journ. ECO, 4, 27-44 (2017)

11. N.V. Lomakina. J. Regionalistics, 5(4), 14-23 (2018) 
12. N.V. Lomakina. J. Management and Business Administration, 3, 22-29 (2013)

13. N.E. Antonova, N.V. Lomakina. J. Sib. Fed. Univ. Humanit. Soc. Sci., 13(4) (2020)

14. V.A. Yatsenko, N.Yu. Samsonov, Ya.V. Kryukov. World of Economics and Management, 18(4), 69-84 (2018)

15. A.B. Bardal', A.N. Dem'janenko, O.V. Djomina, Ja.V. Djomina, N.V. Lomakina, P.A. Minakir. J. Regionalistica. 5 (6). 18-36 (2018)

16. Russian-assembled gas carrier. Kommersant Daily, 221, 7 (02.12.2019). https://www.kommersant.ru/doc

17. A. Kuznetsov. The Far East Development Fund will support the development of Malmyzhskoye field. https://www.hab.kp.ru/daily/27028/4091662/. (13.09.2019)

18. Chukotka Development Foundation. Official webpage. https://fond87.ru/?page_id=504\&lang=ru. Last retrieved on 08.02.2019 